\title{
An empirical study the relationship between intellectual intelligence and university performance
}

\author{
Jamshid Salehi Sadaghiani $^{\mathrm{a}^{*}}$ and Hassan Jamali $^{\mathrm{b}}$
}

${ }^{a}$ Department of Management, Allameh Tabatabae University, Tehran, Iran

${ }^{b}$ Master of Financial Management, Islamic Azad University, South Branch, Tehran, Iran

\begin{tabular}{|c|c|}
\hline A R T I C L E I N F O & A B S T R A C T \\
\hline $\begin{array}{l}\text { Article history: } \\
\text { Received March 22, } 2012 \\
\text { Received in Revised form } \\
\text { May, } 8,2012 \\
\text { Accepted } 11 \text { May } 2012 \\
\text { Available online } \\
\text { May } 142012 \\
\text { Keywords: } \\
\text { Intellectual capital } \\
\text { Human capital } \\
\text { Structural capital }\end{array}$ & $\begin{array}{l}\text { Intellectual capital (IC) is normally used to create value for organizations and in today's } \\
\text { business environment; the success of each organization depends on managing such assets. } \\
\text { During the past few years, many organizations implement IC to increase their competitive } \\
\text { advantages. Hospitals are among business units where IC plays an important role on the success } \\
\text { of these units. People normally choose hospitals based not only based on their equipments but } \\
\text { also based on the specialists and physicians they have. In this paper, we present an empirical } \\
\text { study to measure the impact of IC in accounting parts of hospitals. The results of our regression } \\
\text { analysis indicates that when there is a unit increase in either of human, customer, structural or } \\
\text { intellectual capital individually, we can expect of an increase of } 1.278,1.210,1.415 \text { and } 1.620 \\
\text { units increase in the performance of the university, respectively. }\end{array}$ \\
\hline
\end{tabular}

(C) 2012 Growing Science Ltd. All rights reserved.

\section{Introduction}

Intellectual capital (IC) plays an important role on managing business units and there are many studies confirm that IC is the most important portion of business units. Ramezan (2011) performed a review on hoe IC and organizational organic structure in knowledge society improvement are correlated. The results of this survey supported the older opinions of having positive relationship between organic structure and IC. Therefore, the organic structure can improve IC in the organization. Nemec Rudež and Mihalič (2007) investigated the impact of IC on hotel industry. They explained that the changes of classical IC model and its applications in three different categories including human, structural and relationship capital and attempted to extend the idea in a more comprehensive method in hotel industry. 
They divided the relationship capital into two groups of end-customer-relationship capital, which is only associated with relationships with end-customers and non-end-customer-relationship capital, which includes relationships with other partners. This helps to measure the impact of each IC category on the financial performance of hotel firms, separately. They used this model for the Slovenian hotel industry and reported a positive correlations among all pairs of IC categories. Although IC had a substantial influence on financial performance, the results revealed that only endcustomer relationships proved to have a direct influence on financial performance.

They also recommended that Slovenian hotel management could increase the impact of IC by investment in human capital and information technology. García-Meca and Martínez (2007) investigated the use of IC information in investment decisions and reported that some firm characteristics seem to impact the use of IC information. The results also indicated a significant impact of growth opportunities on IC disclosure by financial analysts. Alcaniz et al. (2011) investigated different theoretical contributions to the IC field to find out where any renewal of theoretical endeavour could be targeted. The bigger part of the existing theoretical corpus is determined to have a normative quality, something specifically evident in policy-oriented contributions on accounting for IC and the continued absence of a critical perspective on IC is disclosed to be a worrying lacuna.

Baum and Silverman (2004) examined whether venture capital (VC)s' impact picking winners or building them by comparing the impacts of startups' alliance, intellectual, and human capital characteristics on VCs decisions to finance them with the impacts of the same conditions on future startup performance. They reported a joint logic, which combines the roles: VCs finance startups that have powerful technology, but are at risk of failure in the short term, and so in request of management expertise. They also confirmed that VCs also appeared to make a common attribution error overemphasizing startups' human capital when building their investment decisions. Hsu and

Fang (2009) performed some interview based survey to investigate the relationships governing IC, organizational learning capability, and new product development performance in Taiwan's IC design industry. They reported that human capital and relational capital help new product development performance through organizational learning capability. Although structural capital positively influences organizational learning capability, managers should focus on possibly negative influences of structural capital on new product development performance. Relational capital is the biggest factor among these three types of IC in Taiwanese chip design companies, structural capital is the second, and human capital is the last one. They also compared three types of IC of Taiwan's large enterprises with those of Taiwan's small and medium enterprises (SMEs) and reported that the relational capital of Taiwan's SMEs was relatively less than that of large enterprises.

Longo and Mura (2011) investigated the impact of IC on employees' satisfaction and retention. They performed a survey on 1117 employees of a large Italian firm leader in the food product market. Structural equations modeling results revealed that IC positively influences the job attitudes examined, although differences appeared among the three dimensions of IC. Specifically, human capital and relational capital did not directly influence employees' job satisfaction and retention. In their opinion, these relationships were fully mediated by structural capital and their results revealed two measures of human resource management practices, which positively impacted IC and also contributed to the improvement of employees' job satisfaction and retention.

Abeysekera and Guthrie (2005) performed an empirical investigation of annual reporting trends of intellectual capital in Sri Lanka. They studied the annual reports of each of the top 30 companies listed on the Colombo Stock Exchange in the period 1998/1999 to 1999/2000, using the 'content analysis' method. The findings revealed that the most reported accounting category during this period was external capital and the second most reported was human capital. There was an increase in the frequency of IC reporting over the 2 years. Interestingly, the individual IC items of each capital 
category reported by firms in Sri Lanka varied from those found in other countries. According to Casey (2010), IC for the livestock industry is required at various levels that range from labourers to university science graduates. Tai and Chen (2009) provided a new evaluation model for IC based on computing with linguistic variable. They proposed a model for IC performance evaluation by combining 2-tuple fuzzy linguistic approach with multiple criteria decision-making method. Based on the proposed model, its feasibility is described by the result of IC performance evaluation for a hightechnology company in Taiwan. Striukova et al. (2008) performed an empirical study into the IC reporting practices of UK firms in four distinct sectors. What makes this report from prior IC reporting investigation is that it analyses a wide range of corporate reports for their IC content. They reported major differences between the elements of IC reported in each sector studied. They also reported that a range of various types of corporate reports were implemented for communicating IC information, and that the annual reports were not a good tool for the proportion of disclosures across all corporate reports analyzed in the study.

In this study, we perform an empirical study on relationship between IC and university performance. The proposed study considers the relationship between human capital, structural capital and customer capital with performance of the university. The organization of this paper first presents details of the survey in section 2 and section 3 presents the results of our survey.

\section{The proposed method}

The study includes all people who work in financial departments of medical university based hospitals. The survey designed a questionnaire in Likert scale, which consists of 40 questions. The questionnaire has already been used for similar survey in Canada and Malaysia and it was validated. We have used Cronbach alpha to find the reliability of the survey and it was calculated as 0.93 , which is well above the acceptable level. We used the following regression function to find the relationship between IC and university performance.

$Y_{i}=\beta_{0}+\beta_{1} X_{i}+\varepsilon_{i}$,

where $X_{i}$ is the independent variable, which includes human capital, structural capital and customer capital, $Y_{i}$ is the dependent variable, which includes university performance, $\beta_{0}$ and $\beta_{1}$ are estimated parameters and $\varepsilon_{i}$ is the error term. The following hypotheses are investigated.

\subsection{The relationship between human capital and university performance}

The first hypothesis is associated with the relationship between human capital and university performance.

$\begin{cases}H_{0}: & \text { There is no meaningful relationship between human capital and university performance. } \\ H_{1}: & \text { There is a meaningful relationship between human capital and university performance. }\end{cases}$

\subsection{The relationship between customer capital and university performance}

The second hypothesis is associated with the relationship between customer capital and university performance.

$\begin{cases}H_{0}: & \text { There is no meaningful relationship between customer capital and university performance. } \\ H_{1}: & \text { There is a meaningful relationship between customer capital and university performance. }\end{cases}$ 


\subsection{The relationship between structural capital and university performance}

The second hypothesis is associated with the relationship between structural capital and university performance.

$\left\{H_{0}\right.$ : There is no meaningful relationship between structural capital and university performance.

$H_{1}$ : There is a meaningful relationship between structural capital and university performance.

\subsection{The relationship between intellectual capital and university performance}

The second hypothesis is associated with the relationship between intellectual capital and university performance.

$\left\{H_{0}\right.$ : There is no meaningful relationship between intellectual capital and university performance.

$\left\{H_{1}\right.$ : There is a meaningful relationship between intellectual capital and university performance.

In addition to regression analysis, we also perform Pearson correlation test to detect any possible relationship between intellectual, customer, structural and human capital and university performance.

\section{The results}

In this section, we present details of our finding for the regression analysis. As we have already discussed, there are four regressions analysis and Table 1 shows details of our regression fit.

\subsection{The relationship between human capital and university performance}

The first hypothesis is associated with the relationship between human capital and university performance. The results of regression analysis is as follows,

$Y_{i}=1.278+0.589 X_{i}+\varepsilon_{i}$

t $\quad 1.528 \quad 6.50$ P-value $=0.000$ Pearson Correlation $=0.589$

As we can observe from the results of regression estimate, t-student value for intercept is not meaningful but the slope maintains a meaningful t-student when the level of significance is $95 \%$. The Pearson correlation represents a meaningful relationship between human capital and university performance. Therefore, the first hypothesis is partially approved.

\subsection{The relationship between customer capital and university performance}

The second hypothesis is associated with the relationship between human capital and university performance. The results of regression analysis is as follows,

$Y_{i}=0.95+1.210 X_{i}+\varepsilon_{i}$

t $\quad 1.2587 .296$ P-value $=0.000$ Pearson Correlation $=0.640$

Again, we realize from the results of regression estimate that t-student value for intercept is not meaningful but the slope maintains a meaningful t-student when the level of significance is $95 \%$. The Pearson correlation represents a meaningful relationship between customer capital and university performance. Therefore, the second hypothesis is partially approved.

\subsection{The relationship between structural capital and university performance}

The third hypothesis is associated with the relationship between structural capital and university performance. The results of regression analysis is as follows, 
$Y_{i}=1.415+0.145 X_{i}+\varepsilon_{i}$

t $\quad 0.8819 .740$ P-value $=0.000$ Pearson Correlation $=0.741$

Similar argument holds for the third hypothesis since the t-student value for intercept is not meaningful but the slope maintains a meaningful t-student when the level of significance is $95 \%$. The Pearson correlation represents a meaningful relationship between structural capital and university performance. Therefore, the third hypothesis is partially approved.

\subsection{The relationship between intellectual capital and university performance}

The last hypothesis is associated with the relationship between intellectual capital and university performance. The results of regression analysis is as follows,

$Y_{i}=-.444+1.620 X_{i}+\varepsilon_{i}$

$\mathrm{t} \quad-0.5809 .260 \mathrm{P}$-value $=0.000$ Pearson Correlation $=0.560$

Similar argument holds for the third hypothesis since the t-student value for intercept is not meaningful but the slope maintains a meaningful t-student when the level of significance is $95 \%$. The Pearson correlation represents a meaningful relationship between intellectual capital and university performance. Therefore, the last hypothesis is partially approved.

In summary, we can conclude that when there is a unit increase in either of human, customer, structural or intellectual capital, we can expect of an increase of 1.278, 1.210, 1.415 and 1.620 units increase in the performance of the university, respectively.

\section{Conclusion}

We have presented an empirical study to measure the impact of IC in accounting sections of hospitals, which are managed on behalf of medical schools in city of Tabriz, Iran. The results of our regression analysis indicated that when there was a unit increase in either of human capital, customer capital, structural capital or intellectual capital individually, we could expect of an increase of 1.278, $1.210,1.415$ and 1.620 units increase in the performance of the hospital, respectively. We have also presented Pearson correlation test to see whether there is any positive correlation among all capital factor with efficiency and the results confirmed the positive relationships.

\section{Acknowledgment}

The authors would like to thank the officials of medical school for providing support in providing necessary information to accomplish this survey.

\section{References}

Abeysekera, I., \& Guthrie, J. (2005). An empirical investigation of annual reporting trends of intellectual capital in Sri Lanka. Critical Perspectives on Accounting, 16(3), 151-163.

Alcaniz, L., Gomez-Bezares, F., \& Roslender, R. (2011). Theoretical perspectives on intellectual capital: A backward look and a proposal for going forward. Accounting Forum, 35(2), 104-117.

Baum, J.A.C., \& Silverman, B. S. (2004). Picking winners or building them? Alliance, intellectual, and human capital as selection criteria in venture financing and performance of biotechnology startups. Journal of Business Venturing, 19(3), 411-436.

Casey, N.H. (2010). Integrated higher learning-An investment in intellectual capital for livestock production. Livestock Science, 130(1-3), 83-94.

García-Meca, E., \& Martínez, I. (2007). The use of intellectual capital information in investment decisions: An empirical study using analyst reports. The International Journal of Accounting, 42(1), 57-81. 
Hsu, Y.H., \& Fang, W. (2009). Intellectual capital and new product development performance: The mediating role of organizational learning capability. Technological Forecasting and Social Change, 76(5), 664-677.

Longo, M., \& Mura, M. (2011).The effect of intellectual capital on employees' satisfaction and retention. Information \& Management, 48(7), 278-287.

Nemec Rudež, H., \& Mihalič, T. (2007). Intellectual capital in the hotel industry: A case study from Slovenia. International Journal of Hospitality Management, 26(1), 188-199.

Ramezan, M. (2011). Intellectual capital and organizational organic structure in knowledge society: How are these concepts related? International Journal of Information Management, 31(1), 88-95.

Striukova, L., Unerman, J., Guthrie, J. (2008). Corporate reporting of intellectual capital: Evidence from UK companies. The British Accounting Review, 40(4), 297-313.

Tai, W.S., \& Chen, C.T. (2009).A new evaluation model for intellectual capital based on computing with linguistic variable. Expert Systems with Applications, 36(2), 3483-3488. 